\title{
Lack of eutrophication in a tallgrass prairie ecosystem over 27 years
}

\author{
Kendra K. Mclauchlan, ${ }^{1,4}$ Joseph M. Craine, ${ }^{2}$ Jesse B. Nippert, ${ }^{2}$ and Troy W. Ocheltree ${ }^{3}$ \\ ${ }^{1}$ Department of Geography, Kansas State University, Manhattan, Kansas 66506 USA \\ ${ }^{2}$ Division of Biology, Kansas State University, Manhattan, Kansas 66506 USA \\ ${ }^{3}$ Department of Forest Resources, University of Minnesota, Saint Paul, Minnesota 55108 USA
}

\begin{abstract}
Many North American grasslands are receiving atmospheric nitrogen $(\mathrm{N})$ deposition at rates above what are considered critical eutrophication thresholds. Yet, potential changes in grassland function due to anthropogenic $\mathrm{N}$ deposition are poorly resolved, especially considering that other dynamic factors such as land use and precipitation can also affect $\mathrm{N}$ availability. To better understand whether elevated $\mathrm{N}$ deposition has altered ecosystem structure or function in North American grasslands, we analyzed a 27-year record of ecophysiological, community, and ecosystem metrics for an annually burned Kansas tallgrass prairie. Over this time, despite increasing rates of $\mathrm{N}$ deposition that are within the range of critical loads for grasslands, there was no evidence of eutrophication. Plant $\mathrm{N}$ concentrations did not increase, soil moisture did not decline, forb diversity did not decline, and the relative abundance of dominant grasses did not shift toward more eutrophic species. Neither aboveground primary productivity nor $\mathrm{N}$ availability to plants increased. The fates of deposited $\mathrm{N}$ in grasslands are still uncertain, and could include management losses through burning and grazing. However, evidence from this grassland indicates that eutrophication of North American grassland ecosystems is not an inevitable consequence of current levels of $\mathrm{N}$ deposition.
\end{abstract}

Key words: eutrophication; grassland; Konza Prairie; nitrogen deposition; precipitation; tallgrass prairie.

\section{INTRODUCTION}

Nitrogen $(\mathrm{N})$ limits primary productivity in many terrestrial ecosystems (Vitousek and Howarth 1991, LeBauer and Treseder 2008), and is a component of a number of greenhouse gases (Pinder et al. 2012). Therefore, alteration of the global $\mathrm{N}$ cycle is expected to have profound effects on terrestrial ecosystem processes and the Earth's climate system (Vitousek et al. 1997, Galloway et al. 2008). As a consequence of fertilizer production, crop selection, and fossil fuel combustion, humans have doubled the production of reactive nitrogen $(\mathrm{Nr})$ on Earth (Galloway et al. 2008). The mobility of $\mathrm{N}$ in the environment often causes anthropogenic $\mathrm{N}$ to be transported from its sources through atmospheric and hydrological pathways, which can lead to regional increases in $\mathrm{N}$ loading (Dentener et al. 2006, Howarth et al. 2012).

Below critical loads, elevated $\mathrm{N}$ deposition should produce few quantitative or qualitative shifts in ecosystem processes. Above critical loads of deposition, nitrogen saturation theory predicts a range of shifts in plant ecophysiology, community composition, and ecosystem processes (Aber et al. 1989, 1998, Lovett and Goodale 2011). Experimentally elevated N deposition has been shown to increase net primary production

Manuscript received 7 June 2013; revised 1 October 2013; accepted 7 October 2013. Corresponding Editor: A. T. Classen.

${ }^{4}$ E-mail: mclauch@ksu.edu and foliar $\mathrm{N}$ concentrations, while greater soil $\mathrm{N}$ availability also increases gaseous $\mathrm{N}$ loss and nitrate leaching to waters (Fenn et al. 1998, Tietema et al. 1998, Gough et al. 2000, Magill et al. 2004). These changes to the $\mathrm{N}$ cycle also increase the natural abundance ratio of ${ }^{15} \mathrm{~N}:{ }^{14} \mathrm{~N}$ in plants and soil $\left(\delta^{15} \mathrm{~N}\right.$ when standardized relative to the signature of atmospheric $\mathrm{N}_{2}$ [Pardo et al. 2007, Craine et al. 2009b]). This is due to an increase in fractionating loss pathways (such as gaseous $\mathrm{N}$ loss associated with nitrification and denitrification) and reduced dependence of plants on mycorrhizal fungi observed with increased $\mathrm{N}$ availability (Hobbie and Hobbie 2008). An increase in $\mathrm{N}$ enrichment can also lead to a shift in plant species composition toward species that are well adapted to high $\mathrm{N}$ availability (Craine et al. 2001, Smith et al. 2009). These changes have been hypothesized to occur in a predictable temporal sequence in terrestrial ecosystems (Aber et al. 1998, Smith et al. 2009), although the sequence of changes is not always consistent (Lovett and Goodale 2011).

Empirically, widespread increases in aboveground net primary productivity (ANPP) have been observed in a variety of $\mathrm{N}$ addition experiments, but the response seems to be dependent on climate and the amount of $\mathrm{N}$ added, with a greater response in high precipitation regions (Lee et al. 2010). A decline in species richness has been the most widespread negative consequence of $\mathrm{N}$ addition, as demonstrated by experiments across dry and wet grasslands in Europe at a range of soil $\mathrm{pH}$ 
(Bobbink et al. 2010). Eutrophication has been observed in a range of terrestrial ecosystems in Europe where $\mathrm{N}$ deposition levels frequently exceed $2 \mathrm{~g} \cdot \mathrm{m}^{-2} \cdot \mathrm{yr}^{-1}$ (Stevens et al. 2004, Payne et al. 2013). However, N deposition levels rarely exceed $1 \mathrm{~g} \mathrm{~N} \cdot \mathrm{m}^{-2} \cdot \mathrm{yr}^{-1}$ in North America (Baumgardner et al. 2002), where terrestrial eutrophication has yet to be broadly demonstrated. Like European grasslands, North American grasslands should be susceptible to $\mathrm{N}$ deposition. Experimental additions of $\mathrm{N}$ to humid grasslands cause changes that are generally consistent with expectations of $\mathrm{N}$ enrichment, for example leading to increases in plant tissue $\mathrm{N}$, primary production, and $\mathrm{N}$ loss, as well as shifts in plant species composition to a lower diversity of high-N species and a decrease in mycorrhizal colonization (Groffman et al. 1993, Wedin and Tilman 1996, Collins et al. 1998, Craine et al. 2001, Egerton-Warburton et al. 2007, Clark and Tilman 2008). Retention of $\mathrm{N}$ in grasslands can cause the effects of elevated $\mathrm{N}$ to persist for a number of years after $\mathrm{N}$ additions cease, leading to suggestions that any amount of $\mathrm{N}$ addition to grasslands leads to loss of ecological function (Clark et al. 2009).

Despite concern about atmospheric $\mathrm{N}$ deposition, it is uncertain whether North American grasslands are actually eutrophying. Grasslands adjacent to urban areas have exhibited signs of localized eutrophication (Weiss 1999), yet there are several reasons that eutrophication may not be happening in most North American grasslands. Deposition rates in many North American grasslands are elevated compared to preIndustrial conditions but below some estimates of critical loads. North American grasslands are also frequently managed with fire, which increase $\mathrm{N}$ losses to the atmosphere (Hobbs et al. 1991, Blair 1997). Furthermore, grasslands dominated by $\mathrm{C}_{4}$ grasses are associated with high soil immobilization potential as a consequence of their production of high $\mathrm{C}: \mathrm{N}$ biomass (Wedin 1995). Examination of potential eutrophication from nutrient loading in grasslands must also simultaneously consider soil moisture. In general, soil $\mathrm{N}$ mineralization rates increase with increasing soil moisture (Stanford and Epstein 1974). Therefore, increases in precipitation could increase net $\mathrm{N}$ mineralization and constitute a form of eutrophication independent of $\mathrm{N}$ deposited from the atmosphere.

To better understand whether atmospheric $\mathrm{N}$ deposition has led to eutrophication in North American grasslands, we examined multiple ecological variables in annually burned tallgrass prairie grassland at Konza Prairie Biological Station in Kansas, USA. In association with the Konza Long-Term Ecological Research program, records of productivity and other metrics extend back more than 25 years and annually harvested biomass has been archived that allows for subsequent chemical analyses. Atmospheric inorganic $\mathrm{N}$ deposition has been measured on-site since 1982, and nutrient addition experiments have demonstrated that $\mathrm{N}$ is an important driver of ecosystem processes at Konza
(Knapp et al. 1998). Grassland aboveground net primary productivity (ANPP) at Konza has been shown to have some of the strongest $\mathrm{N}$ responses among North American grasslands (Clark et al. 2007), suggesting that elevated $\mathrm{N}$ deposition would increase ANPP.

Although multiple drivers affect the functioning of grasslands, if $\mathrm{N}$ deposition is eutrophying a grassland, a majority of the following effects should be detectable: (1) increases in $\mathrm{N}$ availability would lead to increased plant $\mathrm{N}$ concentrations, (2) foliar $\delta^{15} \mathrm{~N}$ in plant tissue would increase as fractionating losses increase, (3) net primary productivity would increase due to reduction in nutrient limitation, and (4) plant species composition would shift toward plants that are adapted to high-N conditions and there would be a reduction of forb diversity.

\section{Methods \\ Study site}

This research was conducted at Konza Prairie Biological Station (hereafter "Konza"; see Plate 1), a 3487-ha native tallgrass prairie located in northeastern Kansas, USA (39.08 ${ }^{\circ}$ N, 96.56 $\left.{ }^{\circ} \mathrm{W}\right)$ (Knapp et al. 1998). Mean annual temperature at Konza is $13^{\circ} \mathrm{C}$, with average monthly temperatures ranging from $-3^{\circ} \mathrm{C}$ in January to $27^{\circ} \mathrm{C}$ in July. Annual precipitation for Konza Prairie averaged $844 \mathrm{~mm}$ from 1983 to 2009, with approximately $75 \%$ falling in the April through September growing season and peak precipitation in June. The vegetation at Konza is primarily unplowed native tallgrass prairie. For the detailed analysis of multiple data types required for this study, we selected a single 42-ha watershed referred to as 1D. This watershed is burned each spring, similar to the dominant land uses in the broader Flint Hills ecoregion, but it is not grazed.

\section{Nitrogen inputs}

Deposition of inorganic $\mathrm{N}\left(\mathrm{NH}_{4}{ }^{+}\right.$and $\left.\mathrm{NO}_{3}{ }^{-}\right)$has been measured at Konza since 1982, as part of the National Atmospheric Deposition Program(data available online). ${ }^{5}$ The collector station adheres to standard NADP protocols. Briefly, precipitation is collected in an automated precipitation chemistry collector. At weekly intervals, it is transferred to containers provided by the Central Analytical Laboratory (CAL) at the Illinois State Water Survey. The collection bucket is weighed to determine sample volume, and samples are shipped to CAL. All analyses for ionic concentrations and quality control occurs at the CAL. At Konza, the collection station is located $5 \mathrm{~km}$ from the $1 \mathrm{D}$ watershed but it is considered to be representative of $\mathrm{N}$ deposition levels in the region (the data are archived as data set ANA01; available online). ${ }^{6}$ Dry deposition has been measured at

\footnotetext{
${ }^{5}$ http://nadp.sws.uiuc.edu/data/

${ }^{6} \mathrm{http}: / /$ www.konza.ksu.edu/knz/pages/data/knzdata.aspx
} 
Konza since 2002 as part of the Clean Air Status and Trends Network (data available online). ${ }^{7}$

Atmospheric $\mathrm{N}$ deposition at this site averaged $0.7 \mathrm{~g}$ $\mathrm{N} \cdot \mathrm{m}^{-2} \cdot \mathrm{yr}^{-1}$ from 2002 to 2009 . This level is above the minimum critical load for herbaceous plants in tallgrass prairie of the Great Plains of North America (0.5-1.5 g $\mathrm{N} \cdot \mathrm{m}^{-2} \cdot \mathrm{yr}^{-1}$ [Pardo et al. 2011]). A recent refinement of the critical load for the Great Plains region, which encompasses wet and dry grasslands, is 0.5 to $1.83 \mathrm{~g}$ $\mathrm{N} \cdot \mathrm{m}^{-2} \cdot \mathrm{yr}^{-1}$ (Clark et al. 2013). The critical load values were primarily determined with an $\mathrm{N}$ addition experiment at Cedar Creek Natural History Area, which is classified as tallgrass prairie but has a mean annual temperature of $6.7^{\circ} \mathrm{C}$ and a mean annual precipitation of $801 \mathrm{~mm}$ (Clark and Tilman 2008).

\section{Plant biomass}

Aboveground net primary productivity was measured at the end of each growing season from 1984 to 2010 by clipping all vegetation in five quadrats $(20 \times 50 \mathrm{~cm})$ in four transects in each of two landscape positions in an annually burned, ungrazed watershed (1D). These sites were established for long-term vegetation monitoring in 1981 (data set PAB011; see footnote 6). The biomass is pooled by year. Clipping dates ranged from 31 August to 14 October among years, but there was no significant relationship between the date of clipping and any measured metric $(P>0.05)$. Each year, biomass was separated into graminoid, forb, and woody components. From 1985 to 2001, aboveground biomass of grass was further separated into live and dead fractions before weighing. All biomass was oven dried before weighing. Graminoid biomass, which is almost all grasses in this watershed, composes $96 \%$ of the herbaceous biomass in the watershed.

At a single site, foliar $\delta^{15} \mathrm{~N}$ values are correlated with $\mathrm{N}$ availability metrics such as in situ and potential net $\mathrm{N}$ mineralization and soil nitrate concentrations (Craine et al. 2009a). We analyzed the nitrogen concentrations ([N]), isotopic composition of nitrogen $\left(\delta^{15} \mathrm{~N}\right)$, and isotopic composition of $\mathrm{C}\left(\delta^{13} \mathrm{C}\right)$ of aboveground grass biomass for one plot for each of two transects per landscape position in the watershed (transects A and B for uplands; C and D for lowlands) each year. Elemental and isotopic analysis for $\mathrm{C}$ and $\mathrm{N}$ were conducted at the Stable Isotope Mass Spectrometry Lab (SIMSL) at Kansas State University using standard methods on a ThermoFinnigan Delta Plus mass spectrometer (Thermo Fisher Scientific, Waltham, Massachusetts, USA) interfaced with a Carlo Erba 1110 elemental analyzer with Conflo II interface (Lakewood, New Jersey, USA). Accuracy, as determined by comparing measured values to the known value of an internal laboratory standard, was better than $0.21 \%$ for $\delta^{15} \mathrm{~N}$ and $0.12 \%$ for $\delta^{13} \mathrm{C}$ across all batches of samples. Precision within each

\footnotetext{
${ }^{7}$ http://epa.gov/castnet/javaweb/index.html
}

batch of samples analyzed, as estimated by the standard deviation of repeated measurements of a working standard, was lower than $0.1 \%$ for $\delta^{15} \mathrm{~N}$ and $0.05 \%$ for $\delta^{13} \mathrm{C}$ across all batches of samples. The isotopic ratio of $\mathrm{N}$ and $\mathrm{C}$ are expressed relative to the internationally accepted standard of atmospheric $\mathrm{N}_{2}$ and Pee Dee Belemnite Vienna (PDBV), respectively. Each metric was measured separately for live and dead biomass from 1985 to 2001 and a final composite metric was calculated for aboveground biomass by weighting the value of each fraction by the relative amounts of live and dead biomass for the plot.

Foliar $\delta^{13} \mathrm{C}$ data were used to calculate changes in carbon isotope discrimination

$$
\Delta=\frac{\delta^{13} \mathrm{C}_{\mathrm{a}}-\delta^{13} \mathrm{C}_{\mathrm{p}}}{1+\frac{\delta^{13} \mathrm{C}_{\mathrm{p}}}{1000}}
$$

where $\delta^{13} \mathrm{C}_{\mathrm{a}}$ and $\delta^{13} \mathrm{C}_{\mathrm{p}}$ are the $\delta^{13} \mathrm{C}$ of air and plant tissue, respectively. Values of $\delta^{13} \mathrm{C}_{\mathrm{a}}$ were obtained from measurements of atmospheric air collected monthly at La Jolla, California, USA (Keeling et al. 2010). Values of $\delta^{13} \mathrm{C}_{\mathrm{a}}$ from April through October were averaged to reflect growing season values.

\section{Plant community composition}

To test for the potential impact of $\mathrm{N}$ deposition on plant community composition, we calculated the longterm relative areal cover of three dominant grasses that respond strongly to $\mathrm{N}$ addition at Konza. Andropogon gerardii and Schizachyrium scoparium are two grass species that dominate N-limited grasslands at Konza. With chronic $\mathrm{N}$ fertilization at the rate of $10 \mathrm{~g}$ $\mathrm{N} \cdot \mathrm{m}^{-2} \cdot \mathrm{yr}^{-1}$, their abundance declines, while Panicum virgatum increases in abundance (Gough et al. 2012). Hence, we calculated the difference in abundance between Panicum and the sum of abundance of Andropogon and Schizachyrium as a way to summarize the $\mathrm{C}_{4}$ grass differential.

Cover data for the three species are derived from 40 plots in the watershed that are divided evenly between upland and lowland positions (data set PVC021; see footnote 6). For each topographic position (uplands and lowlands) in a watershed, species composition was determined in 20 permanently marked $10-\mathrm{m}^{2}$ circular plots evenly spaced along four randomly located $50-\mathrm{m}-$ long transects. At each plot, the canopy cover of vascular plants was visually estimated using a modified Daubenmire cover scale (Bailey and Poulton 1968) twice a year (late May-June and mid August-September). The Daubenmire scale is an ordinal scale ranging from 0 to 7 representing cover classes of $0-1 \%, 1-5 \%, 5-25 \%, 25-$ $50 \%, 50-75 \%, 76-95 \%$, and $95-100 \%$. The cover of each species was recorded as the maximum abundance at the plot level between the two time points after converting each Daubenmire scale value to the midpoint of the cover range and then averaging across the 40 plots for a watershed's topographic position each year. There was 
little qualitative difference in patterns of cover over time when analyzed separately for each topographic position. Forb richness was calculated as the number of forb species observed per $10-\mathrm{m}^{2}$ plot and averaged across all plots in both landscape positions each year.

\section{Soil moisture}

At two locations in the lowlands of the 1D watershed, soil moisture was measured once every other week during the growing season and monthly the rest of the year since 1983 (data set ASM011; see footnote 6). Soil moisture was measured with a neutron depth moisture gauge (Troxler Electronic, Research Triangle Park, North Carolina, USA) in thin-walled aluminum access tubes buried to $2 \mathrm{~m}$ below the soil surface. Readings were taken at $25-\mathrm{cm}$ increments from 25 to $150 \mathrm{~cm}$ depth from 1983 to 2010 . Soil moisture data were expressed as a fraction of the apparent maximum soil moisture based on the highest soil moisture readings observed (Briggs and Knapp 1995, Craine and Nippert 2013). In 1998, a new neutron probe head was employed requiring that data be standardized for differences in maximum soil moisture before and after this date. To do this, the $90 \%$ quantiles of all readings at each depth before and after 1998 were determined. All readings at a given depth for each time period were then divided by the respective value for the $90 \%$ quantile. The $10 \%$ of the relative soil moisture values $>1$ were set to 1 . This standardizes soil moisture readings over time and across depths to have the same maximum value. For simplicity, we only analyze patterns of soil moisture at 25 and $100 \mathrm{~cm}$, which broadly represent the dynamics throughout the profile. Trends in these data are analyzed on biweekly periods from May to September across years, corresponding to 10 half-month periods.

\section{Critical climate period analysis}

We used critical climate period analysis (Craine et al. $2012 a$ ) to remove variation in response metrics that were associated with variation in climate among years and better test whether there were long-term trends in the metrics over time independent of trends in climate. The critical climate period approach is a regression technique that determines when during the year climate variability affects processes and separates the critical periods for climate variation from non-critical periods when climate variation has no significant impact on processes. For the critical climate period analysis, precipitation was summed and daily maximum air temperature averaged for 861 periods between day 60 (1 March) and day 274 (1 October), which approximates the biologically active period for plants in the grassland. Daily climate data were collected from a weather station located at Konza Prairie headquarters, approximately $5 \mathrm{~km}$ away from the $1 \mathrm{D}$ watershed. The number of periods corresponds to all possible periods between the two dates with a minimum length of $15 \mathrm{~d}$ where start and end dates are incremented in 5-d steps, e.g., day $60-74,60-79, \ldots$,
260-274. A forward stepwise regression was initiated using precipitation data and mean daily maximum temperatures from all periods to explain variation in response variables such as grass ANPP. The critical precipitation or temperature period that explained the highest amount of variation in flowering was then selected as a predictor variable and the process repeated for the next most significant climate period. Critical climate periods of the same climate variable that overlapped in time were not allowed in the final model. Critical climate periods were recently assessed for ANPP at Konza for the same year range that we analyze here (Craine et al. 2012a) and not analyzed anew. The previous analysis showed that grass ANPP increased with increasing precipitation from 15 April to 2 August (day of year 105-214) and decreased with increasing mean daily maximum temperatures from 9 July to 2 August (day of year 190-214). As biomass N concentrations could be influenced by the production of low-N stems, we also tested whether variation in $\mathrm{N}$ concentrations of aboveground biomass was influenced by the magnitude of culm production in the watershed (Craine et al. 2010b).

All statistics were computed using the software JMP 9.0.3 (SAS Institute, Cary, North Carolina, USA).

\section{RESUlts}

From 1985 to $2010, \mathrm{NH}_{4}{ }^{+}-\mathrm{N}$ wet deposition averaged $0.26 \pm 0.01 \mathrm{~g} \cdot \mathrm{m}^{-2} \cdot \mathrm{yr}^{-1}$ and increased at a rate of 0.005 $\mathrm{g} \cdot \mathrm{m}^{-2} \cdot \mathrm{yr}^{-1}(P<0.001 ;$ Fig. 1$)$. Over the same period, $\mathrm{NO}_{3}{ }^{-} \mathrm{N}$ wet deposition has averaged $0.23 \mathrm{~g} \cdot \mathrm{m}^{-2} \cdot \mathrm{yr}^{-1}$, but has shown no linear increase or decrease over time $(P=0.41)$. Together, wet $\mathrm{N}$ deposition has averaged 0.50 $\pm 0.02 \mathrm{~g} / \mathrm{m}^{2}$ with a trend for increasing at a rate of 0.004 $\mathrm{g} \cdot \mathrm{m}^{-2} \cdot \mathrm{yr}^{-1}(P=0.06)$. The only significant $(P<0.01)$ trend in climate from 1985 to 2010 was precipitation from 25 May to 19 June, which increased $4.5 \pm 1.6 \mathrm{~mm} /$ yr $\left(r^{2}=0.26, P=0.01\right)$. Precipitation during the precipitation critical climate period for grass ANPP (day of year 105-214) showed no significant change over time ( $P=0.24$; Fig. 1). Dry deposition, measured from 2002 to 2009 , averaged $0.17 \mathrm{~g} / \mathrm{m}^{2}$ and was decreasing at a rate of $0.012 \mathrm{~g} \cdot \mathrm{m}^{-2} \cdot \mathrm{yr}^{-1}$ during this period $(P=0.01)$.

Nitrogen concentration of aboveground biomass ([ $\left.\mathrm{N}_{\mathrm{AG}}\right]$ ) varied by a factor of 2 among years, from 4.5 to $8.3 \mathrm{mg} / \mathrm{g}$ in the uplands and 4.4 to $8.7 \mathrm{mg} / \mathrm{g}$ in the lowlands (Fig. 1). Variation among years in $\left[\mathrm{N}_{\mathrm{AG}}\right]$ were consistent between topographic positions as well as between live and dead biomass (Fig. 1). In years when $\left[\mathrm{N}_{\mathrm{AG}}\right]$ was high in the uplands, it was also high in the lowlands ( $r=0.82, P<0.001, n=22$ samples used in the correlations between variables). Among the years when live and dead biomass were separated from one another, when $\left[\mathrm{N}_{\mathrm{AG}}\right]$ was high in the live biomass, it was also high in the dead biomass $(r=0.75, P<0.001, n=15$; Fig. 2). Variation in $\left[\mathrm{N}_{\mathrm{AG}}\right]$ was associated with variation in end-of-season grass culm biomass. Years with high grass culm biomass had lower [ $\left.\mathrm{N}_{\mathrm{AG}}\right](r=0.64, P<$ 

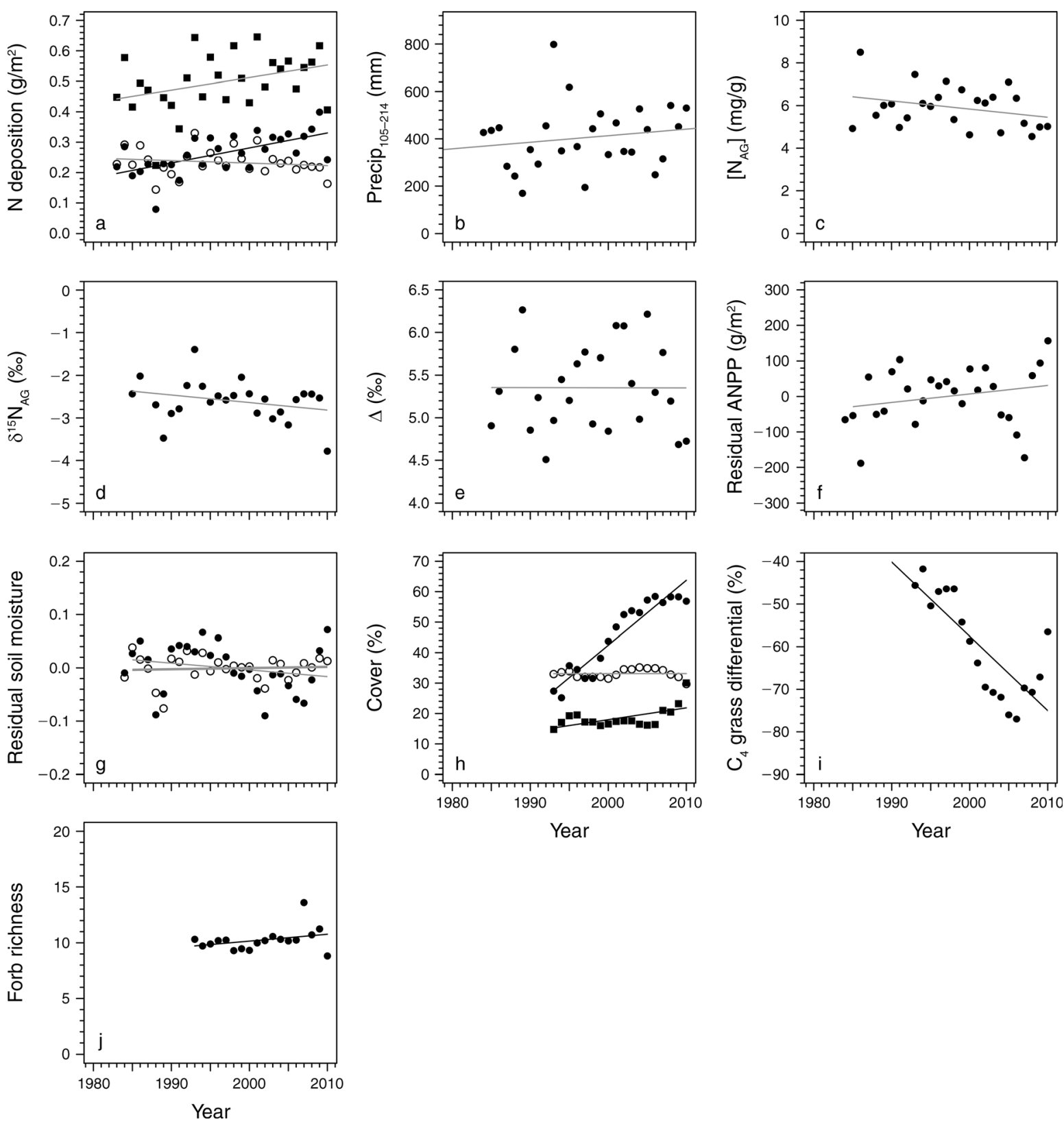

FIG. 1. Patterns in ecophysiological, community, and ecosystem metrics over time. Included are (a) inorganic $\mathrm{N}$ deposition from 1985 to 2010 including $\mathrm{NO}_{3}^{-}$(open circles), $\mathrm{NH}_{4}{ }^{+}$(solid circles), and total inorganic $\mathrm{N}$ (solid squares; $n=28$ samples analyzed); (b) precipitation during the precipitation critical climate period that best explains variation in grass productivity (Precip $_{105-214}$, the precipitation that fell from day 105 (15 April) to day 214 (2 August) of each year; $n=27$ ); (c) aboveground plant $\mathrm{N}$ concentrations ([ $\left.\left.\mathrm{N}_{\mathrm{AG}}\right] ; n=25\right),(\mathrm{d}) \delta^{15} \mathrm{~N}$ of aboveground biomass $(n=25)$; (e) an index of photosynthetic water use efficiency $(\Delta$; $n=25$ ); (f) residual aboveground net primary productivity (ANPP) after accounting for precipitation and temperature during critical climate periods $(n=27)$; (g) residual variation in soil moisture at $25 \mathrm{~cm}$ (solid circles, thin line) and $100 \mathrm{~cm}$ (open circles, thick line) expressed relative to saturation after accounting for critical climate period precipitation and temperature $(n=27)$; (h) the cover of three key grasses over time (Andropogon gerardii [solid circles], Schizachyrium scoparium [open circles], and Panicum virgatum [solid squares]; $n=18$ ); (i) a calculated variable based on changes in the abundance of the three $\mathrm{C}_{4}$ grasses, which scales positively with $\mathrm{N}$ availability $(n=18)$; and (j) forb richness (number of species $/ 10 \mathrm{~m}^{2} ; n=18$ ).

$0.001, n=23$ ), while variation in leaf biomass had no impact on $\left[\mathrm{N}_{\mathrm{AG}}\right](P=0.74)$.

From 1986 to $2010,\left[\mathrm{~N}_{\mathrm{AG}}\right]$ tended to decline with time $(P=0.03$; Fig. 1), but this trend was not significant if the first year of the measurements (1986) was excluded $(P=$ 0.31). At $8.5 \mathrm{mg} / \mathrm{g},\left[\mathrm{N}_{\mathrm{AG}}\right]$ in 1986 was $3 \mathrm{SD}$ greater than the mean $\left[\mathrm{N}_{\mathrm{AG}}\right]$ among years $(5.8 \pm 0.9 \mathrm{mg} / \mathrm{g}[$ mean \pm $\mathrm{SD}]$ ). Controlling for variation in interannual climate or 

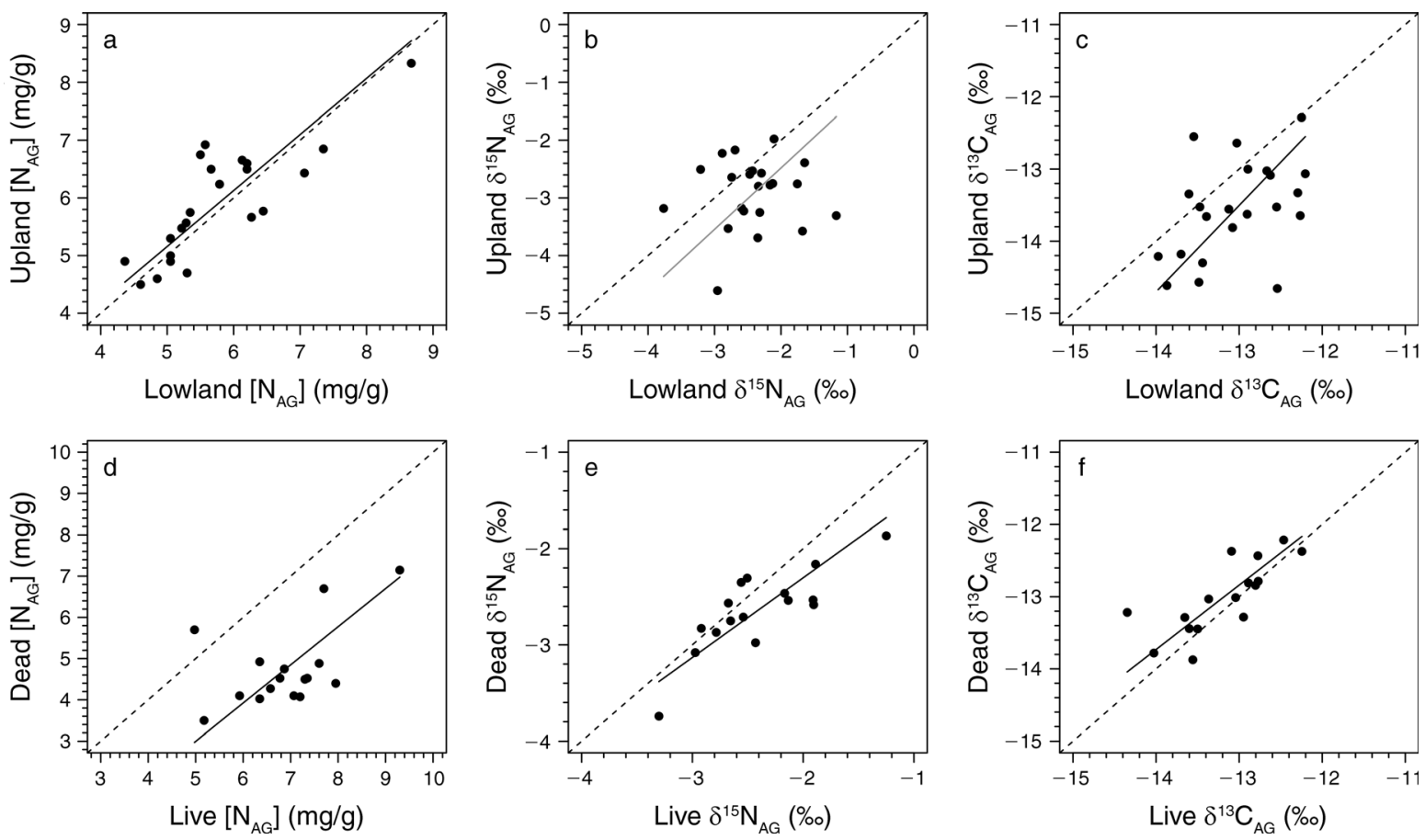

FIG. 2. Relationships between uplands and lowlands or live and dead biomass for three ecosystem metrics. Significant $(P<$ 0.05 , black) and nonsignificant (gray) orthogonal relationships between (a-c) metrics for uplands and lowlands from 1985 to $2010(n=22)$, and $(\mathrm{d}-\mathrm{f})$ live and dead biomass from 1985 to $2001(n=16)$. Included are $(\mathrm{a}, \mathrm{d})$ aboveground plant $\mathrm{N}$ concentrations $\left[\mathrm{N}_{\mathrm{AG}}\right],(\mathrm{b}, \mathrm{e}) \delta^{15} \mathrm{~N}$ of aboveground biomass, and $(\mathrm{c}, \mathrm{f}) \delta^{13} \mathrm{C}$ of aboveground biomass.

grass flowering only reduced any trend for a decline in $\left[\mathrm{N}_{\mathrm{AG}}\right]$. For example, excluding 1986, upland $\left[\mathrm{N}_{\mathrm{AG}}\right]$ decreased with increasing precipitation from 19 June to 14 July $(P<0.001)$, but there was no significant trend in $\left[\mathrm{N}_{\mathrm{AG}}\right]$ across years after accounting for interannual variation in precipitation $(P=0.9)$.

Like plant $\mathrm{N}$ concentrations, plant $\mathrm{N}$ availability, as indexed by isotopic composition of $\mathrm{N}$ in aboveground biomass, showed no significant trend over time. The $\delta^{15} \mathrm{~N}$ of aboveground biomass $\left(\delta^{15} \mathrm{~N}_{\mathrm{AG}}\right)$ varied by $2.9 \%$ within uplands and lowlands among years $(-4.0 \%$ to $-1.1 \%$ for both). $\delta^{15} \mathrm{~N}_{\mathrm{AG}}$ averaged $0.3 \%$ lower in uplands than lowlands $(-2.8 \%$ vs. $-2.5 \%$, respectively; $P=0.03)$, but variation among years in $\delta^{15} \mathrm{~N}_{\mathrm{AG}}$ was not consistent between uplands and lowlands $(P=0.63)$. Interannual variation in climate was not a significant predictor of $\delta^{15} \mathrm{~N}_{\mathrm{AG}}$ for uplands ( $P>0.01$ for all critical climate periods [CCPs]). For lowlands, $\delta^{15} \mathrm{~N}_{\mathrm{AG}}$ decreased with increasing temperature from 15 to 29 March $(P=0.002)$, but this CCP explained the uniquely low $\delta^{15} \mathrm{~N}_{\mathrm{AG}}$ of 1989 and was not significant if that year was excluded $(P>0.05)$. Overall, for both landscape positions, there were no significant linear increases or decreases in $\delta^{15} \mathrm{~N}_{\mathrm{AG}}$ over time ( $P>0.25$ for both).

There was not a temporal trend in $\Delta$, the change in $\mathrm{C}$ isotopic ratio, an index of plant water use efficiency. For uplands, $\Delta$ was less in years with more precipitation from 19 June to 23 July $\left(\Delta=6.41 \%{ }^{-}-0.0063 \%\right.$ o per $\mathrm{mm}$ Precip $_{170-204}$ [the precipitation that fell from day 170 (19
June) to day 204 (23 July) of each year]; $P<0.001$ ). Similarly, in lowlands, $\Delta$ was less in years with more precipitation from 4 June to 9 July, but greater in years with more precipitation from 8 August to 2 October $(\Delta=$ 5.29\%o-0.0055\%o per mm Precip $155-189+0.0052 \%$ per mm Precip $230-274 ; P<0.001$ for all parameters). After accounting for variation in precipitation during critical climate periods among years, there was no significant change in $\Delta$ from 1985 to 2010 , although $\Delta$ tended to increase by $0.014 \%$ per year for uplands $(P=0.14)$ and tended to decrease by $0.012 \%$ per year for lowlands $(P=$ $0.07)$.

There was no indication that soils became wetter or drier on average, regardless of whether differences in climate among years were considered or not $(P>0.25$ for both; Fig. 1). Independent of climate variation in each year, there were no trends in soil moisture at either 25 or $100 \mathrm{~cm}$ for any of the 10 time periods from May to September $(P>0.1$ for all 20 contrasts). In general, critical climate period analysis showed that soils at 25 and $100 \mathrm{~cm}$ were wetter with more precipitation over periods of variable length that were longer for $100 \mathrm{~cm}$ than $25 \mathrm{~cm}(67 \pm 9 \mathrm{~d}$ vs. $33 \pm 9 \mathrm{~d} ; P=0.02$; Table 1$)$. Air temperatures only decreased soil moisture in four of the 20 combinations of depth and time of year. Once interannual variation in precipitation and temperature at different times of year were taken into account for each depth and time period, there were no long-term 
TABLE 1. Critical climate periods for soil moisture at two depths, nitrogen concentrations of aboveground biomass, and an index of photosynthetic water use efficiency.

\begin{tabular}{|c|c|c|c|c|c|c|}
\hline \multirow[b]{2}{*}{ Metric and contrast } & \multicolumn{3}{|c|}{ Precipitation } & \multicolumn{3}{|c|}{ Temperature } \\
\hline & $\mathrm{CCP}$ & $r^{2}$ & $P$ & $\mathrm{CCP}$ & $r^{2}$ & $P$ \\
\hline \multicolumn{7}{|l|}{$\mathrm{SM}_{25}$} \\
\hline Late May & $0-60$ & 0.44 & $<0.001$ & & & \\
\hline Early June & $0-25$ & 0.46 & $<0.001$ & & & \\
\hline Late June & $0-40$ & 0.54 & $<0.001$ & $0-25$ & 0.18 & 0.002 \\
\hline Early July & $0-25$ & 0.52 & $<0.001$ & $5-120$ & 0.16 & 0.001 \\
\hline Late July & $0-20$ & 0.71 & $<0.001$ & & & \\
\hline Early August & $0-30$ & 0.65 & $<0.001$ & & & \\
\hline Late August & $0-50$ & 56 & $<0.001$ & & & \\
\hline Early September & $0-55$ & 0.4 & 0.002 & & & \\
\hline Late Sept & $0-15$ & 0.67 & $<0.001$ & $20-40$ & 0.12 & 0.001 \\
\hline \multicolumn{7}{|l|}{$\mathrm{SM}_{100}$} \\
\hline Late June & $0-40$ & 0.47 & $<0.001$ & & & \\
\hline Early July & $5-60$ & 0.49 & $<0.001$ & $30-60$ & 0.14 & 0.003 \\
\hline Late July & $0-75$ & 0.36 & $<0.001$ & & & \\
\hline Early August & $20-90$ & 0.67 & $<0.001$ & & & \\
\hline Late August & $5-90$ & 0.6 & $<0.001$ & & & \\
\hline Early September & $10-65$ & 0.54 & $<0.001$ & & & \\
\hline Late Sept & $0-75$ & 0.65 & $<0.001$ & & & \\
\hline \multicolumn{7}{|l|}{$\left[\mathrm{N}_{\mathrm{AG}}\right]$} \\
\hline Upland & $170-195$ & 0.52 & $<0.001$ & & & \\
\hline Lowland & $80-105$ & 0.35 & 0.003 & & & \\
\hline \multicolumn{7}{|l|}{$\Delta$} \\
\hline Upland & $170-205$ & 0.50 & $<0.001$ & & & \\
\hline Lowland & $155-190$ & 0.42 & $<0.001$ & & & \\
\hline
\end{tabular}

Notes: Critical climate periods (CCP) are shown for soil moisture (SM) at two depths (25 and $100 \mathrm{~cm}$ ), aboveground nitrogen concentrations ([N $\left.\mathrm{N}_{\mathrm{AG}}\right]$ ), and carbon isotope discrimination $(\Delta)$. For soil moisture, critical climate periods shown are relative to the day soil moisture was sampled in a given half month period each year. For example, $0-60$ for $25 \mathrm{~cm}$ in late May signifies that precipitation from $60 \mathrm{~d}$ to the day of sampling increased soil moisture. For other metrics, periods are the days of year that define the CCPs. Nonsignificant time periods are not shown; for $\mathrm{SM}_{25}$, this was early May, and for $\mathrm{SM}_{100}$, this was early May, late May, and early June.

trends in soil moisture in any of the 10 time periods (average $P=0.44 ; P>0.1$ for all contrasts).

Grass productivity showed no evidence of increasing over time after accounting for interannual variation in climate. From 1984 to 2010, grass ANPP had been shown to increase with increasing mid-summer precipitation and decreased with higher mid-summer temperatures. Both before and after accounting for variation in climate among years, there were no significant trends in grass biomass averaged between uplands and lowlands $(P=0.18$ for both; Fig. 1). Forb biomass only averaged $20 \mathrm{~g} / \mathrm{m}^{2}$ (5\% of grass ANPP), was not related to interannual variation in climate $(P>0.01)$, and showed no trend across years $(P=0.27)$.

Changes in the composition of the grass flora from 1993 to 2010 do not seem to indicate an increase in grassland $\mathrm{N}$ availability. Although species-specific total cover has increased an average of $0.019 \mathrm{~cm}^{2} \cdot \mathrm{cm}^{-2} \cdot \mathrm{yr}^{-1}$, the changes in the dominant grasses do not parallel changes observed with experimental $\mathrm{N}$ addition (Fig. 1). Averaged between uplands and lowlands, the cover of grasses associated with low-N environments increased. Andropogon increased by an average of 0.021 $\mathrm{cm}^{2} \cdot \mathrm{cm}^{-2} \cdot \mathrm{yr}^{-1}(P<0.001)$ while Schizachyrium cover did not change $(P=0.97)$. Panicum, which increases in abundance with experimental $\mathrm{N}$ fertilization, did increase slightly in abundance, but at an average of only $0.0038 \mathrm{~cm}^{2} \cdot \mathrm{cm}^{-2} \cdot \mathrm{yr}^{-1}(P=0.01)$. Although the cover of Andropogon increased faster than Panicum on average for the period 2006-2010, the calculated variable of the $\mathrm{C}_{4}$ grass differential declined significantly from 1993 to $2010\left(-0.017 \mathrm{~cm} \cdot \mathrm{cm}^{-2} \cdot \mathrm{yr}^{-1}, P<0.001\right)$. Forb diversity averaged $10.2 \pm 1.0$ species $/ 10 \mathrm{~m}^{2}$ across years, but there was no significant change in forb diversity over time $(P=$ 0.19, Fig. 1).

\section{Discussion}

Although $\mathrm{N}$ is being deposited from the atmosphere onto grassland ecosystems in the midcontinental United States at rates that are considered to be within the range of critical loads (Pardo et al. 2011), there was no evidence of eutrophication in the Konza grassland for ecophysiological, community, or ecosystem parameters. Despite expectations that ecophysiological traits are among the first to respond to chronic shifts in resource availability (Smith et al. 2009), neither foliar N concentrations nor $\Delta$ significantly changed over 27 years. At the community level, the common grasses did not show a trend of increasing abundance of more eutrophic grass species as observed in $\mathrm{N}$ addition 


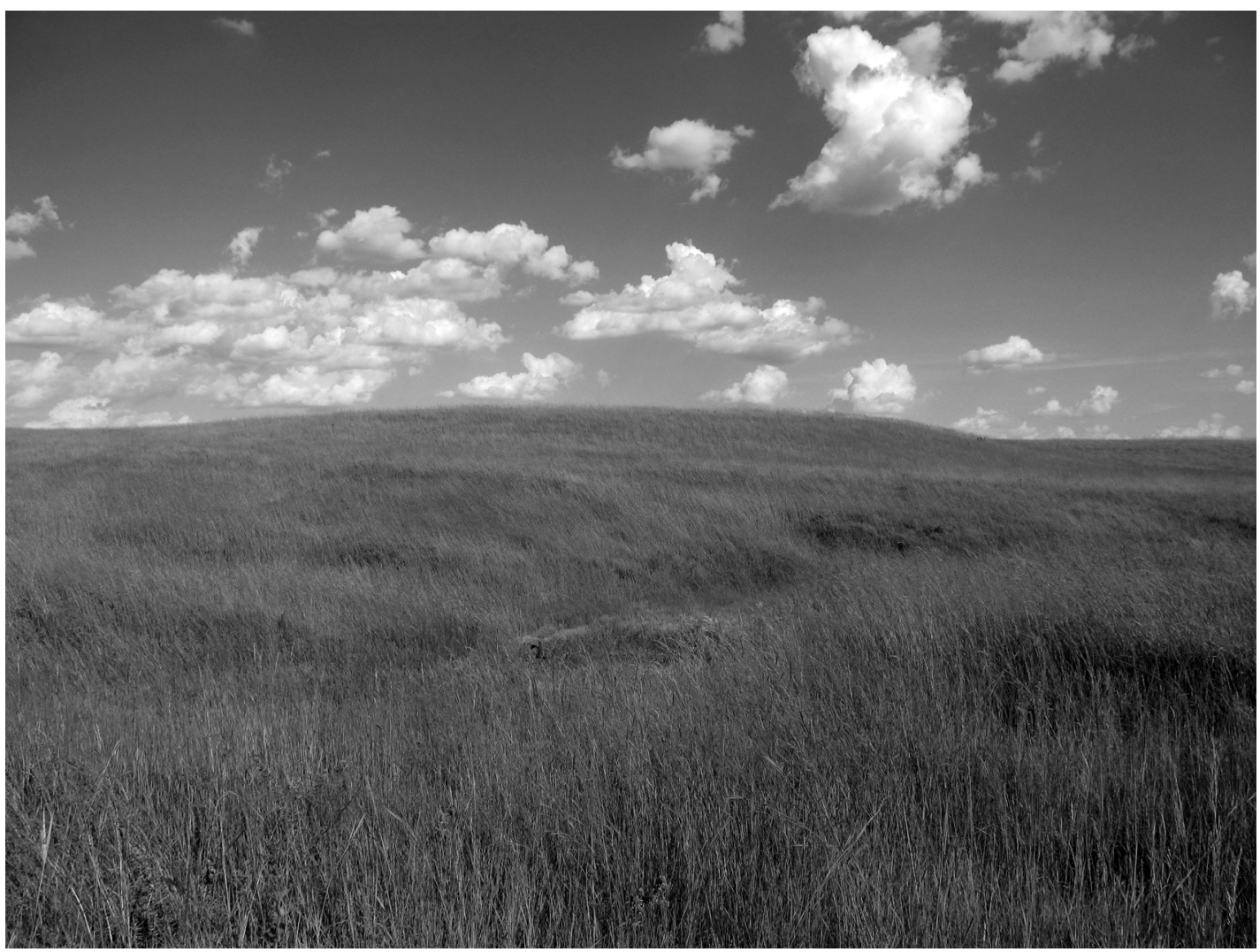

Plate 1. The 1D watershed at Konza Prairie Biological Station, Kansas, USA. Photo credit: J. B. Nippert.

experiments (Isbell et al. 2013). Neither did total species richness decline as predicted, even among the rare forbs. For ecosystem metrics, there were no trends in grass productivity, flowering culm production of the major grasses, or aboveground biomass $\delta^{15} \mathrm{~N}$ (an index of $\mathrm{N}$ availability to plants).

Phosphorus (P) limitation has the potential to reduce the response of grasslands to $\mathrm{N}$ deposition. For example, a transect through temperate Eurasia across a range of atmospheric $\mathrm{N}$ deposition levels (from 50 $\mathrm{kg} \cdot \mathrm{ha}^{-1} \cdot \mathrm{yr}^{-1}$ to $5 \mathrm{~kg} \cdot \mathrm{ha}^{-1} \cdot \mathrm{yr}^{-1}$ ) suggested that $\mathrm{P}$ limitation is a potential reason for a lack of species loss due to $\mathrm{N}$ deposition (Wassen et al. 2005).Yet, $\mathrm{P}$ limitation is unlikely to explain the apparent lack of response to $\mathrm{N}$ deposition at Konza. A long-term fertilization experiment with $\mathrm{P}\left(1 \mathrm{~g} \mathrm{P} \cdot \mathrm{m}^{-2} \cdot \mathrm{yr}^{-1}\right)$ in factorial with $\mathrm{N}$ showed no evidence of $\mathrm{P}$ limitation after 20 years of experimental additions to an annually burned grassland at Konza (Gough et al. 2000).

Precipitation can also potentially affect both the $\mathrm{N}$ cycle and NPP independent of $\mathrm{N}$ dynamics. For example, long-term increases in precipitation would increase plant productivity in a manner similar to eutrophication (Collins et al. 1998, Knapp et al. 2001). In contrast, if $\mathrm{N}$ deposition increased plant transpiration by increasing leaf $\mathrm{N}$ concentrations and/or leaf area, soil moisture would decline, which could serve as a negative feedback to $\mathrm{N}$ availability. Reductions of precipitation that dry soils could also mask the effects of $\mathrm{N}$ deposition. Here, the critical climate period analysis indicates that long-term variability in precipitation and soil moisture is neither causing nor inhibiting potential ecosystem responses to atmospheric $\mathrm{N}$ deposition.

In understanding the degree of eutrophication in grasslands that would result from $\mathrm{N}$ deposition, management will need to be considered. The Konza watershed examined here is burned annually. Burning volatilizes $\mathrm{N}$ at a relatively low temperature (Wan et al. 2001) and could maintain $\mathrm{N}$ limitation in the face of increasing $\mathrm{N}$ deposition. Given the end-of-season values for aboveground biomass and its $\mathrm{N}$ concentration, an average of $2.4 \mathrm{~g} \mathrm{~N} / \mathrm{m}^{2}$ is present in the aboveground biomass at the end of the season. It is unknown how much $\mathrm{N}$ is retained in the biomass over the winter before the late spring burning, but this would represent an upper estimate of annual $\mathrm{N}$ losses for the watershed. Yet, to compare this study to other grasslands, the watershed studied here (1D) is not grazed. Grazers accumulate $\mathrm{N}$ during the year, which is exported with the animals. For comparison, nearby grasslands have typical cattle production of $93 \mathrm{~kg} \cdot \mathrm{ha}^{-1} \cdot \mathrm{yr}^{-1}$ (Owensby et al. 1995), which would be approximately $1.6 \mathrm{~g}$ $\mathrm{N} \cdot \mathrm{m}^{-2} \cdot \mathrm{yr}^{-1}$ exported in cattle biomass each year (Baker et al. 2001). Thus, removals of $\mathrm{N}$ from grassland systems 
through burning and/or grazing have the potential to offset atmospheric $\mathrm{N}$ deposition, at least when considering the input and output rates alone.

One additional fate of the deposited $\mathrm{N}$ could be the large soil organic matter pool (Blair 1997). Net sequestration into soil organic matter could also be contributing to the lack of response to deposition. This has recently been observed in forested systems of the eastern United States (Lovett et al. 2013). In our study, surface soils $(0-20 \mathrm{~cm})$ in the $1 \mathrm{D}$ watershed have a $\mathrm{C}: \mathrm{N}$ of 12.7 (Craine et al. 2010a) with soil organic matter concentrations high enough such that if all the deposited $\mathrm{N}$ over the study period were sequestered into the top 20 $\mathrm{cm}$ of soil organic matter, soil $\mathrm{N}$ concentrations would increase only $2 \%$. Atmospheric $\mathrm{CO}_{2}$ concentrations have also increased by 45 ppm (13\%) from 1984 to 2010 , which could be promoting $\mathrm{N}$ limitation in the face of increased deposition (Gill et al. 2002).

Given that $\mathrm{N}$ supplies via deposition have been increasing at this site, understanding why $\mathrm{N}$ availability has not changed requires a theoretical framework for $\mathrm{N}$ cycling that incorporates feedbacks and lags (Lovett and Goodale 2011), alongside a better biogeochemical budget and targeted measurements of flux pathways such as gaseous $\mathrm{N}$ loss rates. For example, gaseous $\mathrm{N}$ loss is limited by nitrate availability at Konza (Groffman et al. 1993) and could be a major avenue for $\mathrm{N}$ loss that counteracts increased deposition. Yet significant elevated gaseous $\mathrm{N}$ loss would increase the $\delta^{15} \mathrm{~N}$ of available N and subsequently plants (Högberg 1990), unless portions of the nitrate pools were completely denitrified (Houlton et al. 2006). Past work has shown no indication of increasing $\mathrm{NO}_{3}{ }^{-}$loss in streams at Konza (Kemp and Dodds 2001) and groundwater $\mathrm{NO}_{3}{ }^{-}$ concentrations are relatively low in the area (Macpherson 1998).

Reconstructions of $\mathrm{N}$ availability from herbarium samples collected from Kansas grasslands suggested that $\mathrm{N}$ became more limiting in those ecosystems during the 20th century (McLauchlan et al. 2010). Across a broad suite of grassland species (including $\mathrm{C}_{4}$ grasses), foliar $\mathrm{N}$ concentrations and $\delta^{15} \mathrm{~N}$ began declining in the first half of the 20th century. Although the $\mathrm{N}$ concentrations of aboveground biomass tended to decline, the Konza grass biomass reported here cannot be tested for declines in foliar $\mathrm{N}$ concentrations due to biomass being measured at the stand level, which included culms as well as foliar biomass. Yet, based on patterns observed in $\mathrm{C}_{4}$ grasses in herbarium samples, $\delta^{15} \mathrm{~N}$ would have been expected to decline by $1.6 \%$ from 1984 to 2010 . The observed interspecific variation in plant $\delta^{15} \mathrm{~N}$ at Konza could be larger than the regional temporal pattern of decline in foliar $\delta^{15} \mathrm{~N}$ (Craine et al. 2012b).

The lack of a terrestrial eutrophication signal in this grassland has important management implications for $\mathrm{N}$ in the mid-continental U.S. Although atmospheric $\mathrm{N}$ inputs are potentially an important part of the $\mathrm{N}$ budget, our results indicate that these ecosystems can receive three decades of $\mathrm{N}$ deposition without demonstrating the earliest predicted biotic consequences of $\mathrm{N}$ saturation theory. Additionally, if changes in some aspects of grassland functioning are observed to be consistent with eutrophication, it will be critical to test hypotheses about if these changes were caused by (1) $\mathrm{N}$ deposition, (2) climate, especially precipitation, or (3) changes in management regimes such as increased grazing or reduced burning. Multiple environmental variables may cause effects that parallel eutrophication from atmospheric $\mathrm{N}$ deposition.

The concept of critical loads has been used to suggest that grasslands of the Great Plains will be experiencing significant losses of herbaceous plant diversity under current atmospheric $\mathrm{N}$ deposition levels (Clark et al. 2013). These critical load values $\left(5-15 \mathrm{~kg} \mathrm{~N} \cdot \mathrm{ha}^{-1} \cdot \mathrm{yr}^{-1}\right)$ were developed in the tallgrass prairie biome in Minnesota, which has a colder climate than Konza, but also lower ANPP than Konza due to sandy parent material and past land use history that depleted soil organic matter stocks (Knops and Tilman 2000). At the minimum, the data presented here imply that the critical load estimates for some grassland ecosystems will need to be revised.

More broadly, some have suggested that there is no minimum critical load for grasslands (Payne et al. 2013), and that human societies have crossed a "boundary" with regard to the global $\mathrm{N}$ cycle (Rockstrom et al. 2009). Although there are uncertainties, our results suggest that eutrophication is not an inevitable fate of all ecosystems receiving atmospheric $\mathrm{N}$ deposition. Many terrestrial ecosystems are experiencing static and declining $\mathrm{N}$ availability (Bernal et al. 2012), requiring continued examination of the possible degree and extent of eutrophication.

\section{ACKNOWLEDGMENTS}

We thank the Konza Prairie Long-Term Ecological Research Program for collecting, archiving, and sharing data and samples. Partial funding for this project was provided by a grant from the National Science Foundation (DEB-0823341). Graciela Orozco and Amanda Kuhl assisted with sample preparation. We thank Walter Dodds and John Blair for helpful discussion.

\section{Literature Cited}

Aber, J., W. McDowell, K. Nadelhoffer, A. Magill, G. Berntson, M. Kamakea, S. McNulty, W. Currie, L. Rustad, and I. Fernandez. 1998. Nitrogen saturation in temperate forest ecosystems - hypotheses revisited. BioScience 48:921934.

Aber, J. D., K. J. Nadelhoffer, P. Steudler, and J. M. Melillo. 1989. Nitrogen saturation in northern forest ecosystems. BioScience 39:378-386.

Bailey, A. W., and C. E. Poulton. 1968. Plant communities and environmental interrelationships in a portion of Tillamook Burn Northwestern Oregon. Ecology 49:1-13.

Baker, L. A., D. Hope, Y. Xu, J. Edmonds, and L. Lauver. 2001. Nitrogen balance for the Central Arizona-Phoenix (CAP) ecosystem. Ecosystems 4:582-602.

Baumgardner, R. E., T. F. Lavery, C. M. Rogers, and S. S. Isil. 2002. Estimates of the atmospheric deposition of sulfur and 
nitrogen species: Clean Air Status and Trends Network, 1990-2000. Environmental Science and Technology 36:26142629.

Bernal, S., L. O. Hedin, G. E. Likens, S. Gerber, and D. C. Buso. 2012. Complex response of the forest nitrogen cycle to climate change. Proceedings of the National Academy of Sciences USA 109:3406-3411.

Blair, J. M. 1997. Fire, N availability, and plant response in grasslands: a test of the transient maxima hypothesis. Ecology 78:2359-2368.

Bobbink, R., et al. 2010. Global assessment of nitrogen deposition effects on terrestrial plant diversity: a synthesis. Ecological Applications 20:30-59.

Briggs, J. M., and A. K. Knapp. 1995. Interannual variability in primary production in tallgrass prairie: climate, soil moisture, topographic position, and fire as determinants of aboveground biomass. American Journal of Botany 82:1024-1030.

Clark, C. M., E. E. Cleland, S. L. Collins, J. E. Fargione, L. Gough, K. L. Gross, S. C. Pennings, K. N. Suding, and J. B. Grace. 2007. Environmental and plant community determinants of species loss following nitrogen enrichment. Ecology Letters 10:596-607.

Clark, C. M., S. E. Hobbie, R. Venterea, and D. Tilman. 2009. Long-lasting effects on nitrogen cycling 12 years after treatments cease despite minimal long-term nitrogen retention. Global Change Biology 15:1755-1766.

Clark, C. M., P. E. Morefield, F. S. Gilliam, and L. H. Pardo. 2013. Estimated losses of plant biodiversity in the United States from historical N deposition (1985-2010). Ecology 94: 1441-1448.

Clark, C. M., and D. Tilman. 2008. Loss of plant species after chronic low-level nitrogen deposition to prairie grasslands. Nature 451:712-715.

Collins, S. L., A. K. Knapp, J. M. Briggs, J. M. Blair, and E. M. Steinauer. 1998. Modulation of diversity by grazing and mowing in native tallgrass prairie. Science 280:745-747.

Craine, J. M., et al. 2009a. Global patterns of foliar nitrogen isotopes and their relationships with climate, mycorrhizal fungi, foliar nutrient concentrations, and nitrogen availability. New Phytologist 183:980-992.

Craine, J. M., et al. 2009b. Global patterns of foliar nitrogen isotopes and their relationships with climate, mycorrhizal fungi, foliar nutrient concentrations, and nitrogen availability. New Phytologist 183:980-992.

Craine, J. M., J. Froehle, D. G. Tilman, D. A. Wedin, and F. S. Chapin, III. 2001. The relationships among root and leaf traits of 76 grassland species and relative abundance along fertility and disturbance gradients. Oikos 93:274-285.

Craine, J. M., and J. B. Nippert. 2013. Cessation of burning dries soils long-term in a tallgrass prairie. Ecosystems. http:// dx.doi.org/10.1007/s10021-013-9706-8

Craine, J. M., J. B. Nippert, A. J. Elmore, A. M. Skibbe, S. L. Hutchinson, and N. A. Brunsell. 2012a. Timing of climate variability and grassland productivity. Proceedings of the National Academy of Sciences USA 109:3401-3405.

Craine, J. M., R. Spurr, K. K. McLauchlan, and N. Fierer. 2010a. Landscape-level variation in temperature sensitivity of soil organic carbon decomposition. Soil Biology and Biochemistry 42:373-375.

Craine, J. M., E. G. Towne, and J. B. Nippert. 2010b. Climate controls on grass culm production over a quarter century in a tallgrass prairie. Ecology 91:2132-2140.

Craine, J. M., E. G. Towne, T. W. Ocheltree, and J. B. Nippert. $2012 b$. Community traitscape of foliar nitrogen isotopes reveals $\mathrm{N}$ availability patterns in a tallgrass prairie. Plant and Soil 356:395-403.

Dentener, F., et al. 2006. Nitrogen and sulfur deposition on regional and global scales: a multimodel evaluation. Global Biogeochemical Cycles 20.
Egerton-Warburton, L. M., N. C. Johnson, and E. B. Allen. 2007. Mycorrhizal community dynamics following nitrogen fertilization: a cross-site test in five grasslands. Ecological Monographs 77:527-544.

Fenn, M. E., M. A. Poth, J. D. Aber, J. S. Baron, B. T. Bormann, D. W. Johnson, A. D. Lemly, S. G. McNulty, D. E. Ryan, and R. Stottlemyer. 1998. Nitrogen excess in North American ecosystems: predisposing factors, ecosystem responses, and management strategies. Ecological Applications 8:706-733.

Galloway, J. N., A. R. Townsend, J. W. Erisman, M. Bekunda, Z. C. Cai, J. R. Freney, L. A. Martinelli, S. P. Seitzinger, and M. A. Sutton. 2008. Transformation of the nitrogen cycle: recent trends, questions, and potential solutions. Science 320: 889-892.

Gill, R. A., H. W. Polley, H. B. Johnson, L. J. Anderson, H. Maherali, and R. B. Jackson. 2002. Nonlinear grassland responses to past and future atmospheric $\mathrm{CO}_{2}$. Nature 417: 279-282.

Gough, L., K. L. Gross, E. E. Cleland, C. M. Clark, S. L. Collins, J. E. Fargione, S. C. Pennings, and K. N. Suding. 2012. Incorporating clonal growth form clarifies the role of plant height in response to nitrogen addition. Oecologia 169: 1053-1062.

Gough, L., C. W. Osenberg, K. L. Gross, and S. L. Collins. 2000. Fertilization effects on species density and primary productivity in herbaceous plant communities. Oikos 89 : $428-439$.

Groffman, P. M., C. W. Rice, and J. M. Tiedje. 1993. Denitrification in a tallgrass prairie landscape. Ecology 74 : 855-862.

Hobbie, E. A., and J. E. Hobbie. 2008. Natural abundance of $\mathrm{N}-15$ in nitrogen-limited forests and tundra can estimate nitrogen cycling through mycorrhizal fungi: a review. Ecosystems 11:815-830.

Hobbs, N. T., D. S. Schimel, C. E. Owensby, and D. S. Ojima. 1991. Fire and grazing in the tallgrass prairie: contingent effects on nitrogen budgets. Ecology 72:1374-1382.

Högberg, P. 1990. Forests losing large quantities of nitrogen have elevated nitrogen-15:nitrogen-14 ratios. Oecologia 84 : 229-231.

Houlton, B., D. Sigman, and L. Hedin. 2006. Isotopic evidence for large gaseous nitrogen losses from tropical rainforests. Proceedings of the National Academy of Sciences USA 103: 8745-8750.

Howarth, R., D. Swaney, G. Billen, J. Garnier, B. Hong, C. Humborg, P. Johnes, C.-M. Mörth, and R. Marino. 2012. Nitrogen fluxes from the landscape are controlled by net anthropogenic nitrogen inputs and by climate. Frontiers in Ecology and the Environment 10:37-43.

Isbell, F., P. B. T. D. Reich, S. E. Hobbie, S. Polasky, and S. Binder. 2013. Nutrient enrichment, biodiversity loss, and consequent declines in ecosystem productivity. Proceedings of the National Academy of Sciences USA. http://dx.doi.org/ 10.1073/pnas. 1310880110

Keeling, R. F., S. C. Piper, A. F. Bollenbacher, and S. J. Walker. 2010. Monthly atmospheric $13 \mathrm{C} / 12 \mathrm{C}$ isotopic ratios for 11 SIO stations. In Trends: a compendium of data on global change. Carbon Dioxide Information Analysis Center, Oak Ridge National Laboratory, U.S. Department of Energy, Oak Ridge, Tennessee, USA.

Kemp, M., and W. Dodds. 2001. Spatial and temporal patterns of nitrogen concentrations in pristine and agriculturallyinfluenced prairie streams. Biogeochemistry 53:125-141.

Knapp, A. K., J. M. Briggs, D. C. Hartnett, and S. L. Collins. 1998. Grassland dynamics. Oxford University Press, New York, New York, USA.

Knapp, A. K., J. M. Briggs, and J. K. Koelliker. 2001. Frequency and extent of water limitation to primary 
production in a mesic temperate grassland. Ecosystems 4:1928.

Knops, J. M. H., and D. Tilman. 2000. Dynamics of soil nitrogen and carbon accumulation for 61 years after agricultural abandonment. Ecology 81:88-98.

LeBauer, D. S., and K. K. Treseder. 2008. Nitrogen limitation of net primary productivity in terrestrial ecosystems is globally distributed. Ecology 89:371-379.

Lee, M., P. Manning, J. Rist, S. A. Power, and C. Marsh. 2010. A global comparison of grassland biomass responses to $\mathrm{CO}_{2}$ and nitrogen enrichment. Philosophical Transactions of the Royal Society B 365:2047-2056.

Lovett, G. M., M. A. Arthur, K. Weathers, R. D. Fitzhugh, and P. H. Templer. 2013. Nitrogen addition increases carbon storage in soils, but not trees, in an eastern U.S. deciduous forest. Ecosystems 16:980-1001.

Lovett, G. M., and C. L. Goodale. 2011. A new conceptual model of nitrogen saturation based on experimental nitrogen addition to an oak forest. Ecosystems 14:615-631.

Macpherson, G. L. 1998. Nitrate loading of shallow ground water, prairie vs. cultivated land, northeastern Kansas, USA. Pages 165-168 in G. B. Arehart and J. R. Hulston, editors. Proceedings of the Ninth International Symposium on Water-Rock Interaction, Taupo, New Zealand, 30 March3 April 1998. A. A. Balkema, Rotterdam, The Netherlands.

Magill, A. H., J. D. Aber, W. S. Currie, K. J. Nadelhoffer, M. E. Martin, W. H. McDowell, J. M. Melillo, and P. Steudler. 2004. Ecosystem response to 15 years of chronic nitrogen additions at the Harvard Forest LTER, Massachusetts, USA. Forest Ecology and Management 196:7-28.

McLauchlan, K. K., C. J. Ferguson, I. E. Wilson, T. W. Ocheltree, and J. M. Craine. 2010. Thirteen decades of foliar isotopes indicate declining nitrogen availability in central North American grasslands. New Phytologist 187:1135-1145.

Owensby, C., R. Cochran, K. Anderson, E. Smith, and E. Vanzant. 1995. 50 years of range research revisited. Kansas State University, Manhattan, Kansas, USA.

Pardo, L. H., et al. 2011. Effects of nitrogen deposition and empirical nitrogen critical loads for ecoregions of the United States. Ecological Applications 21:3049-3082.

Pardo, L. H., S. G. McNulty, J. L. Boggs, and S. Duke. 2007. Regional patterns in foliar N-15 across a gradient of nitrogen deposition in the northeastern US. Environmental Pollution 149:293-302.

Payne, R. J., N. B. Dise, C. J. Stevens, D. J. Gowing, and BEGIN partners. 2013. Impact of nitrogen deposition at the species level. Proceedings of the National Academy of Sciences USA 110:984-987.

Pinder, R. W., E. A. Davidson, C. L. Goodale, T. L. Greaver, J. D. Herrick, and L. Liu. 2012. Climate change impacts of US reactive nitrogen. Proceedings of the National Academy of Sciences USA 109:7671-7675.

Rockstrom, J., et al. 2009. A safe operating space for humanity. Nature 461:472-475.

Smith, M. D., A. K. Knapp, and S. L. Collins. 2009. A framework for assessing ecosystem dynamics in response to chronic resource alterations induced by global change. Ecology 90:3279-3289.

Stanford, G., and E. Epstein. 1974. Nitrogen mineralizationwater relations in soils. Soil Science Society of America Journal 38:103-107.

Stevens, C. J., N. B. Dise, J. O. Mountford, and D. J. Gowing. 2004. Impact of nitrogen deposition on the species richness of grasslands. Science 303:1876-1879.

Tietema, A., A. W. Boxman, M. Bredemeier, B. A. Emmett, F. Moldan, P. Gundersen, P. Schleppi, and R. F. Wright. 1998. Nitrogen saturation experiments (NITREX) in coniferous forest ecosystems in Europe: a summary of results. Environmental Pollution 102:433-437.

Vitousek, P. M., J. D. Aber, R. H. Howarth, G. E. Likens, P. A. Matson, D. W. Schindler, W. H. Schlesinger, and D. G. Tilman. 1997. Human alteration of the global nitrogen cycle: source and consequences. Ecological Applications 7:737-750.

Vitousek, P. M., and R. W. Howarth. 1991. Nitrogen limitation on land and in the sea-how can it occur? Biogeochemistry 13:87-115.

Wan, S., D. Hui, and Y. Luo. 2001. Fire effects on nitrogen pools and dynamics in terrestrial ecosystems: a meta-analysis. Ecological Applications 11:1349-1365.

Wassen, M. J., H. O. Venterink, E. D. Lapshina, and F. Tanneberger. 2005. Endangered plants persist under phosphorus limitation. Nature 437:547-550.

Wedin, D. A. 1995. Species, nitrogen and grassland dynamics: the constraints of stuff. Pages 253-262 in C. Jones and J. H. Lawton, editors. Linking species and ecosystems. Chapman and Hall, New York, New York, USA.

Wedin, D. A., and D. Tilman. 1996. Influence of nitrogen loading and species composition on the carbon balance of grasslands. Science 274:1720-1723.

Weiss, S. B. 1999. Cars, cows, and checkerspot butterflies: nitrogen deposition and management of nutrient-poor grasslands for a threatened species. Conservation Biology 13:1476-1486. 